\title{
COMPARATIVE OVERVIEW OF NATURAL AND CULTURAL COMPONENTS OF THE MARKETING ENVIRONMENT FOR TOURISM IN KAZAKHSTAN AND SLOVAKIA
}

\author{
Jaroslav Kultan \\ PhD, Associate professor \\ Department of Applied Informatics \\ University of Economics Bratislava, Slovakia \\ Abu Mukhammedov \\ DrSc, Professor \\ Department of Finance and Accounting \\ University of International Business, Kazakhstan \\ Luidmyla Dorokhova \\ $\mathrm{PhD}$, Associate professor \\ Department of Pharmaceutical Management and Marketing \\ National University of Pharmacy, Ukraine \\ Volodymyr Malyi \\ DrSc, Professor \\ Department of Pharmaceutical Management and Marketing \\ National University of Pharmacy, Ukraine \\ Oleksandr Dorokhov \\ $\mathrm{PhD}$, Associate professor \\ Department of Information Systems \\ Simon Kuznets Kharkiv National University of Economics, Ukraine \\ e-mail: aleks.dorokhov@meta.ua
}

\begin{abstract}
Despite the current catastrophic reduction of tourism services and related services in the world in a pandemic, the development of tourism in the long run remains very relevant, especially in anticipation of the reformatting of the global tourism market as one of the results of the end of the pandemic. At the same time, along with the traditional world centers of tourism, we can assume the emergence of new regional and global countries, leaders in tourism. The forthcoming restart of the market will provide a good, rare opportunity for new tourist destinations to express themselves, intensify the attraction of tourists and take certain positions in the resetting tourist market. Therefore, working out their potential and realizing their competitive marketing advantages is important for such tourism-developing countries. Accordingly, this study is devoted to the development of the tourism industry, in particular, the description and analysis of natural conditions and relevant opportunities for the development of health, sports, educational tourism in the Slovak Republic and the Republic of Kazakhstan. A detailed comparative analysis of sociocultural and natural-geographical components of the marketing environment for the development of tourism in both countries is given. Such popular and demanded in international tourism areas as mountain and skiing, cultural-historical and cognitive, medical and health-improving, as well as recreational tourism are considered in detail. In general, the countries in question have much in common regarding the diverse opportunities and types of tourism. However, due to a number of historical, geographical, socio-social reasons, the level of development of tourist services in them is very different. This study also compares opportunities for the development of relevant tourism in Slovakia and Kazakhstan. In order to present tourism for foreign tourists and create a positive image of Slovakia and Kazakhstan as favorable countries for inbound tourism, it is necessary to actively use modern information technologies and innovations. This article presents such sources of information about tourism potential as websites, links to Internet resources of travel agencies and operators, the main video resources about tourism opportunities in the Republic of Kazakhstan. The development of these innovations will allow the Republic of Kazakhstan to become one of the most competitive countries in the tourist service and become a new significant world tourist center.
\end{abstract}

Keywords: Kazakhstan touristic potential, Slovakia tourist benefits, tourism marketing

Introduction. Tourism is mass phenomenon of the XX century. Modern tourism is beginning to develop according to political and economic situation in a developed society in the middle of XIX century. People in the majority - employees, universally deserved the legal right to an annual short (2-3 weeks per year) holidays. The long period of world wars and disasters slowed down the development of tourism, but in the period after the Second World War, a large part of humanity lives quietly, without global turmoil, victims of destruction. 
People, for the most part, settled in individual countries have to live in abundance, allowing, without any effort to allocate from its budget (or receive subsidized) certain funds for short-term vacation and travel for recreational purposes. Vehicle development opened the era of transcontinental flights on aircraft and provided them an affordable opportunity to visit almost any corner of the world. Much of the civilized society has adopted the concept of tourism and laws that promote its development.

Slovakia is amazingly picturesque country is situated in the heart of Europe, protected on three sides by the Carpathian Mountains, and on the South side washed by the waters of the Danube. So, Slovakia is becoming a popular touristic place, the country has a lot to offer: breathtaking landscapes, mountains, caves, medieval towns and castles, wooden architecture, ski resorts and spa sanatorium.

According to the geographical position of Kazakhstan is a unique region. Being in the center of the Eurasian continent, it is special and natural complex blended of the brightest examples of both landscapes of the continent. The tourism potential of Kazakhstan is rich. Kazakhstan has a unique opportunity for the development of almost all types of tourism from the cognitive-related visits to cultural, historical sites and other active forms of tourism, ecotourism. The country has about 100 water hospitals, more than 9,000 archaeological and historical monuments. Popular among tourists is hunting and fishing, including national types of hunting.

Currently tourism in the Republic of Kazakhstan declared as priority, in connection with which the state plans to create the conditions for the formation of a highly efficient and competitive tourism industry, with the aim to further integrate into the structure of the global tourism market and deepening international cooperation in the tourism.

Kazakhstan has a unique natural potential. The country has all opportunities for the development different types of tourism: cultural, educational, environmental, extreme, business, health and others.

According to international experts in tourism, development of the tourism industry in Kazakhstan is progressive and sustainable last years. Although country owns only 53 tourism places in the world for foreign tourists, however, in the coming years, the country has the opportunity to reach a higher level in world tourism rankings.

Literature review. Let consider some latest publications related to the development of tourism in both countries: for Kazakhstan firstly, and for Slovakia. So, the article [1] presents a general assessment of the socio-economic consequences of tourism for Kazakhstan. There have been sustained trends in the economic and social impact of tourism from 2003 to 2019.

The work [7] examines the competitiveness of Kazakhstan in world tourism. It is noted that the country has risen quite high in the world rankings. For further success, it is necessary to pay attention to the experience of other, in particular, European countries.

The paper [10]substantiates the requirement to improve the information environment, information support of tourism activities to enhance the attractiveness of the tourist region, motivation of consumers to visit this territory. Information technology opens up new opportunities for marketing in tourism. Kazakhstan with its unique natural, distinctive culture has a rich untapped potential for the development of tourism in the international market.

At the present stage of development of world tourism, Kazakhstan is becoming an attractive country for extreme recreation, studying the history and modernity of Central Asia, the Great Silk Road. The tourist potential of the recreational, historical and cultural resources of Kazakhstan is also practically not yet revealed and is very promising.

The study [9] analyzes the prospects and potential of health tourism in Kazakhstan. It is noted that health tourism is one of the priority areas in Kazakhstan, and is rapidly developing. However, further marketing activities in the international tourism market are advisable.

In [4] the tourist potential of Kazakhstan and objects of tangible and intangible cultural heritage for ethnocultural tourism are investigated. The concept of cultural heritage is proposed and its use for ethnocultural tourism is substantiated.

It has been developing since the 1980s and at first concerned only material objects (household items, historical and architectural monuments and places). Then an interest arose in the methods of processing materials, crafts, household and economic rituals, customs of ethnic groups. The traditional way of life in Kazakhstan is of interest to tourists and can be the basis for the successful development of international ethnocultural tourism.

The article [13] describes business tourism in Kazakhstan. The perspectives of its development in the light of globalization, entry into the world business community are presented. The expediency of using natural and cultural tourism resources as additional marketing advantages of Kazakhstan in business tourism is emphasized.

At the same time, the article [12]analyzes the features and marketing of rural tourism in Kazakhstan, including the proposed ways of developing rural tourism. The paper [3] analyzes the current state of inbound tourism in the Republic of Kazakhstan as a whole. 
The key problems hindering its development are identified and the ways of their solution are proposed. Finally, a detailed overview in [2] presents, identifying, summarizes the main existing problems of the tourism sector in Kazakhstan, and suggesting ways to solve them.

A number of scientific publications are also devoted to the development of tourism in Slovakia. The study [11] notes that Slovakia has remarkable nature, biodiversity and resources for related geotourism.

Article [6] analyzes the components of health and hygiene as an important factor in the development of tourism.

The development of active and health tourism in national parks in Slovakia is discussed in [8]. Such natural objects are places for individual recreational activities, communication with nature. Sports tourism is also developing in natural parks, with the participation of tourists in massive organized sports events, including competitive ones.

Although there is a change in social needs for physical development through tourism, there is still no strategic approach to the development of sports tourism in the national parks of Slovakia.

Authors in [5] notes that the spa industry is now an essential part of Slovak tourism. This article substantiates the development and importance of spa tourism and wellness, their main problems, sources and directions of development. An overview of balneological tourism, health resorts in Slovakia, places of accommodation, number of visits is given. The functional and spatial typification of spa tourism and wellness in Slovakia has also been carried out.

Summarizing the literature, one can imagine tourism, its constituent parts, elements and structural components in the form of a tree, presented in Figure 1. Of course, all of its elements have a marketing component, and the corresponding marketing approaches, methods, models of promotion, advertising, positioning, impact on a potential consumer.

Aims. The aim of the research is to study the possibilities of tourism development in Kazakhstan and Slovakia and compare them. It is supposed to execute comparative analysis of socio-cultural and natural-geographical components of the marketing environment for tourism development in both countries. It is also necessary to consider the use of modern information technologies for the development and promotion of tourism services and services, in particular, tourism Internet marketing resources.In order to conduct a comparative analysis of the tourism development in Slovakia and Kazakhstan, we will consider separately every basic kinds of tourism activities and possibilities.

Methods. The main method of our research is the search and collection of information using the Internet, as well as its subsequent analysis, systematization and generalization. This approach is becoming the main one, and often one of the few still possible for an ordinary consumer, in the context of a global pandemic at the present time. Moreover, the Internet has become widespread, fairly accessible, easy to use and not burdensome in cost for the bulk of consumers of travel services.

Results and discussion. The analysis of many sources showed that one of the most popular, demanded and competitive in both countries was winter physical culture and sports, in particular, ski tourism.

Mountain and ski tourism include biking, hiking, walking trails providing passage through mountainous terrain, overcoming passes above 3000-3500 m, passing rocky areas, steep slopes, glaciers, snowfields, mountain rivers. For mountaineering use special equipment: ice ax, mountain boots, "cat", rock and ice pitons, carbins, ropes, etc. Of course, ski tourism requires special training of participants and high attention of organizers.

In the winter Slovakia is the best ski resort in Europe. High Tatras: Old Smokovec, Tatranska Lomnica, Strbske Pleso on picturesque lake, Bistra, Demanovska Valley with the most beautiful caves: Demänovská cave of freedom, Demänovská ice cave, Važecká cave, Botska valley. Yasna is the best resort of Eastern Europe. Most of Slovakia territory are mountains: Low Tatras, High Tatras, the Carpathian arc. Snow lies in the mountains of Slovakia from December to April, so the ski season is very long in this country.

The best ski resort in Slovakia is Yasna. It is situated in the Low Tatras, one of the cleanest areas in Europe. Yasna offers for tourists everything that is necessary for skiers: trails of different difficulty levels, multiple lifts, equipment rental, cozy hotels, restaurants and spas. In addition to these man-made components of a good holiday, the Low Tatras are rich in stunning scenery and fresh air. Not far from the resort (about an hour) is the airport, once the military, and now purely civilian, Poprad-Tatry. The airport is small, it serves a few flights, but has a fleet of rescue and medical helicopters.

Kazakhstan also has many possibilities to develod ski tourism. For example, well kmown "Shymbulak Ski Resort" is located in the beautiful Zailiyskiy Alatau mountain at 2,260 m above sea level. It is $25 \mathrm{~km}$ from the city center of Almaty City and has an average temperature of $+25 \mathrm{C}$ in the summer and- $7 \mathrm{C}$ in the winter. The average snowfall is around $1,5 \mathrm{M}$. It is usually very sunny as the average number of sunny days a year can reach $90 \%$. Ski season is normally begins in December and can run into April.

The ski slopes are served by gondola cars from "Medeu" to the base of "Shymbulak", $2260 \mathrm{~m}$ above sea level. This gondola is the world's thirdlongest gondola with a length of $4.5 \mathrm{~km}$. The gondola has 114 comfortable cabins for all guests 
of the resort and has the capacity of 2,000 people per hour. The ski resort has six lifts that service the mountain. Two combination lifts have both quad-chairs and 8 passenger cabins, two quadchairlifts (Leviy Tlagar), one T-bar lift and a Magic
Carpet. The lift system will take you to Talgar pass where you are 3,180 $\mathrm{m}$ above sea level. A vertical rise of $920 \mathrm{~m}$. The mountain views with snowy slopes and evergreen Tien Shan firs are spectacular and must be seen.

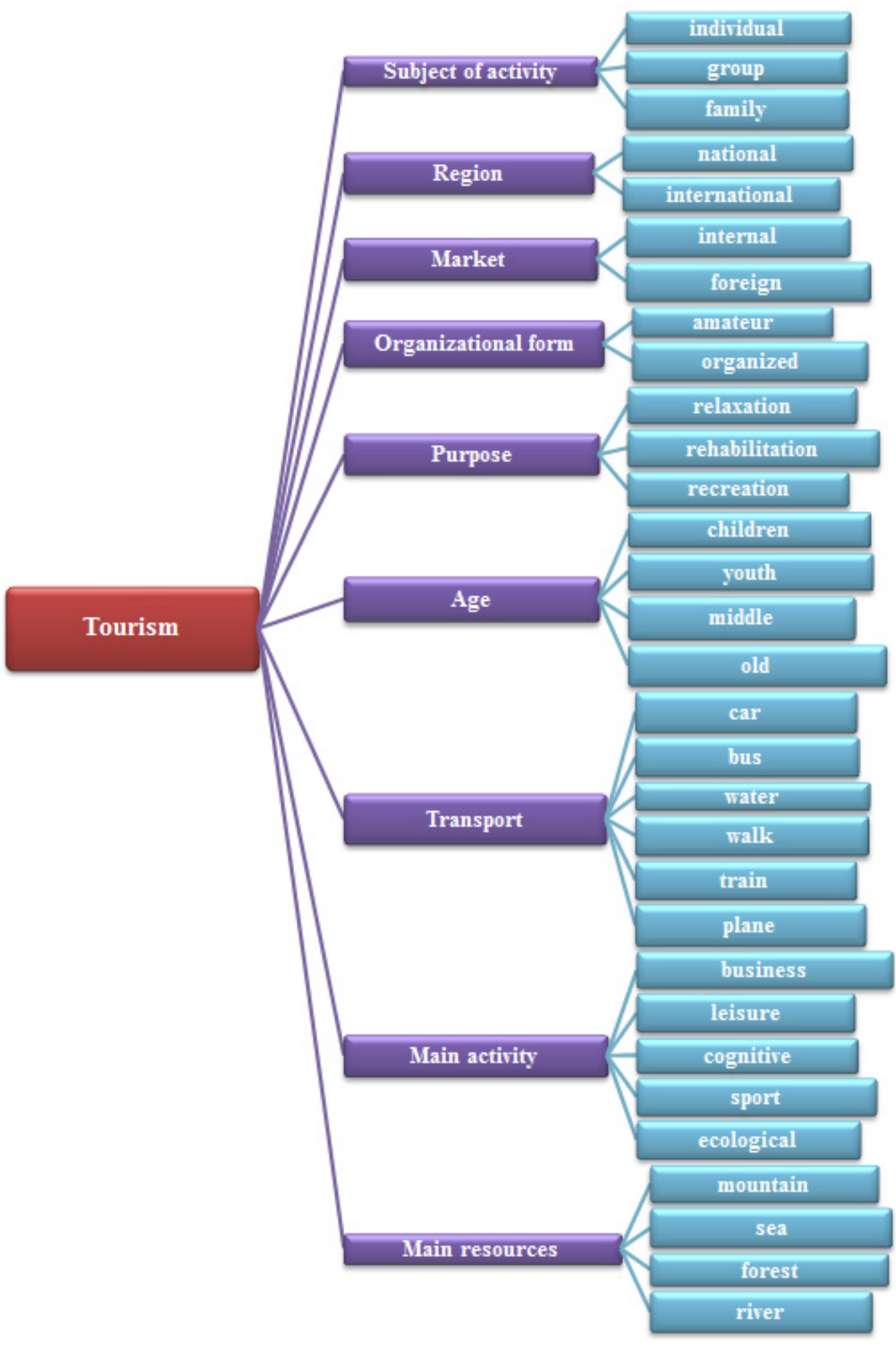

Fig. 1. The main components of tourism Developed by the authors

Shymbulak - this is a place that has something for everyone with a variety of routes, including the soft and gentle slopes for beginners and intermediates skiers and snowboarders as well longer trails for the experts., Shymbulak has a FIS downhill, wild valleys with untouched snow and terrain park for new-scholars, and special routes with moguls. Every year Shymbulak makes improvements to the trails.

Shymbulak has 3,620 meters of certified trails by International Ski Federation (FIS). In addition, there are many off-piste lines for expert skiers and 
snowboarders. And if you have never stood on skis or a snowboard - it means it's time to learn. Experienced instructors from our Snow School will gladly help you with equipment and teach you the skills to enjoy more of the mountain. You can learn all styles: freestyle, slopestyle, carving, or just a refresher to start your holiday right. Rentals of ski and snowboard are available along with locker facilities. Located in the resort is a hotel, restaurants, cafe, and coffee shop with a variety of cuisine to suit all tastes.

Shymbulak is a place to relax, not only in winter, but also in summer! The beauty of the mountains is incomparable and must be seen and appreciated. At the foot of the wild and unexplored mountains are long valleys, which are covered with pine forests, amazingly beautiful meadows. And in the summer, camps for children are running. Development plans of expansion are planned within the complex, increasing the length of the cable car as well as other improvements to the slopes and trails.

So, Shymbulak Ski Resort" is really a great prospect and is a favorite place for recreation and entertainment for Almaty residents, and tourists.

Cultural and historical tourism are another possiblilities for both countries. This type of international tourism, coupled with an acquaintance of tourists with national culture, customs, traditions and historical monuments in the host country.

Besides the magnificent nature slovakia is rich of cultural and historical monuments. In Slovakia you can find all monuments of historical periods. Cities of Eastern Slovakia are built in the Gothic style. A large number of forts and castles scattered throughout the country.

The most famous of them are: the ruins of Spis Castle, founded in the twelfth century (UNESCO site), Trenčin Castle, founded in the eleventh century, Bratislava Castle and the ruins of Devin, built in the tenth century, the Old Town Hall of the thirteenth century, the Palace Praymits (XVIII cent. ), Cathedral of St. Martin (fourteenth and fifteenth centuries.) Mansion Segner (XVII century.) and Roland Fountain (XVI c.), the Kapitulskiy, Klariska, Laurinska and Panská streets, Slovak National Gallery, the Municipal Museum, which is sitated in the Old Hall.

Nitra - Old Slavonic fortified settlement Castle, Franciscan Church, Monastery, Palace (XVIII c.), Column (XVIII cent.) and Abbey Library in Old Seminary of the XVIII century. Banska Styavnitsa - Old Castle (XVI c.), building of Mountain and Forest Academy, monuments of mining industry, the city is included in the UNESCO World Heritage List. The world's tallest Gothic altar is situated in Levoča . Kezmarok - Gothic castle of the XV century with chapel XVII., the ruins of the medieval city walls and castle.

Perhaps the most popular monuments of medieval Kazakhstan architecture are religious buildings. They are mausoleums and mazars ("the home of the dead"). Became widely known Babaji Khatun and Aisha-Bibi mausoleums, built respectively in X-XI and XI-XII centuries; Zhoshy Khan and Alash-khan (near Zhezkazgan) mausoleums relating to the thirteenth century; Zhuban Ana, Kaip-ata, Maulim-Berdi; Kara Khan Mausoleum in Taraz and others. In order to really experience the history and culture of Kazakhstan it is necessary to visit the ancient cities of Kazakhstan. They are Turkestan, Otrar Ispijab (Sairam) Syutkent, Sygnak, Kok Kesene, Sauran, Taraz, Suyab, Dzhend, Saraichuk. Many of these towns were situated on the Great Silk Road.

Turkestan is located in the South-Kazakhstan region, $180 \mathrm{~km}$ north-west of the administrative center - Shymkent. The first settlement on the site of the modern city was born in early 6th century BC. In the 12 th century it preached a famous Sufi poet and mystic, a great teacher of the Turkic peoples - Khoja Ahmed Yasawi. In the 14th century Tamerlane's troops came here for conquest, who in order to get the trust of the steppe nomads renamed this city to Yassy for honor of Khoja Ahmed Yassayi. Later Yassy got a new name - Turkestan. In the 16th century Turkestan was chosen as the capital of the Kazakh Khanate, and remained so until the 19th century.

Otrar located in Syrdarya valley, at the confluence of the rivers Syr Darya and Arys. In science, this area is called Otrar oasis, the ancient name of which Tarband, Turarband, Turar, Farab. An interesting fact is that Farab is home of an outstanding scientist, thinker, philosopher, Aristotle's follower - Abu Nasr al-Farabi. Mausoleum of Khoja Akhmed Yassaui - this magnificent building was named after Akhmet Yassaui, who was living in XII century and well known in the East. He was a head Turkic branch of Sufism, a thinker, a poet. Akhmed Yassaui mausoleum complex is located in the Turkestan city of South Kazakhstan region. It built in the period from 1385 to 1405 years. It includes in the UNESCO World Heritage List. Mausoleum of Arystan-Bab situated in 150 kilometers from Shymkent city, near with the Otrar town. It was named after preacher of Islam, a religious mystic who was lived in the XII century, teacher and spiritual mentor of H.A.Yassaui, Arystan Bab. It is architectural monument of XIV century.

According to the legend, by order of Emir Timur over the tomb of Khoja Ahmed Yassaui began construction of the mosque (1338-1405). All attempts to erect walls failed due to the fault suddenly appear green bull that destroyed everything. In Timur's dream saint said that first you need to build a mausoleum over the tomb of St. Arystan Baba, and then over the grave H.A. Yassaui. Timur did it. Therefore, the pilgrims $t$ the first visited the mausoleum of the first teachers Arystan Bab, and then Khoja Ahmed Yassaui mausoleum. Koran is presented in the 
mausoleum as magnificent example of medieval calligraphy.

Nowadays many tourists prefer medical and health tourism. What are they? Medical and health tourism - kind of tourism committed with wellness or therapeutic purposes. The resort provides tour complexes of therapeutic treatments, massage services etc.

About 1400 mineral springs were opened on the territory of Slovakia. To the east of the country, 6 kilometers from the town of Bardejov, the Bardeëvskie resort has 12 mineral springs bicarbonate, hydrochloric sodium, iron-sour, cold, hypotonic, and with a high content of boric acid. Height of resort is $325 \mathrm{~m}$ above sea level, it is surrounded by pine forests, where you can practice hiking, and the air is filled with minerals. The resort Piestany was founded in 1889. It is situated in the valley of the river Vah, $80 \mathrm{~km}$ from Bratislava. Its mineral water and sulphurous mud used as treatment of rheumatism and arthritis. The main treatments offered to patients are baths, showers, gym and massage.

Smrdaky is a small and quiet resort, it is situated in $80 \mathrm{~km}$ from Bratislava and in $60 \mathrm{~km}$ from Piestany. Mineral water with high content of hydrogen sulfide in Central Europe and sapropelic mud are used for medicinal purpose. Resort Bardejovske Pools located in Eastern Slovakia, it is $435 \mathrm{~km}$ from Bratislava, $80 \mathrm{~km}$ from Kosice and $98 \mathrm{~km}$ from Poprad surrounded by woods. There are used 13 springs for the treatment.

Dudince is relatively young thermal resort in Slovakia, one of the warmest places in the country. It is located in the southern part of the country on the slopes of the central Krupinska basin. Dudince carbonated water began to be used for therapeutic purposes in the early 20th century, and in 1983, when Dudince received the status of the resort, two balneological centers "Ruby" and "Smaragd began to comprehensively treat various ailments. Later they were joined by "Krishtyal" and "Diamond" and remodeled resort pension "Agat".

Queen Elizabeth I, who was better known as Sisi had visited Dudince. Sulfates, hydrogen sulfide, calcium-magnesium and fluorinecontaining mineral springs function in Trencian Greenhouse. The resort treats diseases of the musculoskeletal system, the nervous disorders and post-traumatic conditions.

Rajecke Greenhouse is a small but popular thermal resort in the north-western part of Slovakia, which sutiated in 15 kilometers from the city of Zilina. Rajecke Greenhouse lies between two rivers - Rajcianka and Kuneradka; Surrounded by the forests of the hill Sulov. The city's population is small, only about 2,800 people. There is very clean, unpolluted air with a minimum amount of dust. For the most part, this resort is popular with tourists from within Slovakia and the Czech Republic, Poland and Germany. Guests of Rajecke
Greenhouse love it for its colorful and charming appearance, healing thermal springs as well as the atmosphere of peace and relaxation. Around town is picturesque nature with mountain scenery, rich flora and fauna of the world of the Carpathians. You can see foxes, badgers, deer, owls, eagles and martens.

Pantotheraphy is main brand of East Kazakhstan. Every year hundreds of people travel to stag farm to improve their health and gain strength for the whole year. Antler baths are considered a powerful folk method for radiculitis, gastric ulcer, atherosclerosis of extremities, rheumatism, dystonia, sexual weakness, body purification and other diseases. Especially popular in Eastern medicine for centuries - deer antlers.

According to east medicine antlers are seen as a means of prolonging life, and recently experimentally proved that antler drugs retard aging. The unique ability of deer antlers is stimulate and maintain male potency. Peter I said about this in Russia, thanks to his efforts deer farms had appeared and used for the preparation of medicine. Only in 2000 with the involvement of scientists from different areas it was realized the unique technology of the concentrate from the deer blood and get the drug (powder), with exceptional biological activity and named " Dry Pantogematogen". With the advent of these drugs Pantotheraphy became possible to provide at any time of the year, not just during the cutting antlers.

"Ok Zhetpes" sanatorium of Burabai Medical Center Office of the President of the Republic of Kazakhstan is situated in Shuchinsk-Burabai resort area, located at the foot of Kokshetau Mountain. Okzhetpes and Zhumbaktas rock are near with this place. Sanatorium is known for his biography, his attractiveness and personality. In "Ok Zhetpes" sanatorium every guest will find a necessary treatment and rest. Guests will be carrying and welcoming by professionals of Kazakhstan's health system. The resort quality management system is in accordance with international standards ISO 9001: 2000. The resort provides treatment and prevention for the following diseases: cardiovascular disease, respiratory system, musculoskeletal system, digestive system, circulatory system, endocrine and nervous systems, urological and gynecological diseases. The basic procedure for the treatment of these diseases is included in the price. More information about procedures, you can see in the "Treatment, included in the price."

Saryagash Sanatorium is located $130 \mathrm{~km}$ south of the regional center of Shymkent and $18 \mathrm{~km}$ from the capital of Uzbekistan, Tashkent. The resort is located in the village area Kokterek of Saryagash district in Southern Kazakhstan, at an altitude of $450 \mathrm{~m}$ above sea level, in the gardening area near the river Keles. Everyone is familiar with the unique properties of the mineral water source 
"Saryagash". More than one generation is recuperating due to this unique water.

Realizing the importance of this indicator, the team of health workers are carrying out this work in 5 areas: combating depression, psychotherapy; sanatorium mode, rest; motional mode, exercises, sports games; food / diet therapy; Fighting Obesity / unloading diet, talk with gastroenterologists; struggle with bad habits: alcohol and smoking. The pride of the resort in these sultry places it is a green park. In the early 70-ies of the last century, with efforts of sanatorium staff were planted tens of thousands of tree seedlings of wide variety of species in clayey, poor soil.

It was challenge to preserve them and give them life. Acacia, maple, ash, oak, elm, fruit trees and even noble chestnut now adorn the hospital. Advantageof resort "Saryagash" over others is that the treatment is carried out natural mineral water from the source, the presence of mud therapy, salt mine, intravenous laser irradiation of blood, qualified medical personnel (doctors and nurses with the highest and the first category), reasonable cost of the permit, winter $20 \%$ of discount, the entire healing process is put on the standards and accredited by the Ministry of Health of Kazakhstan.

Sanatorium "Moiyldy" is pleased to offer you our services for disease prevention, health restoration and enjoyable vacation. Main therapeutic factors of sanatorium are mud and brine, extracted from natural lake located at the sanatorium, and a source of mineral water. Medical indications for mud therapy: disease of musculoskeletal system, peripheral nervous system diseases, diseases of female genitalia and uro andrological disease.

Mineral water is recommended for internal use as therapeutic and outdoor use after heating in the form of baths, irrigation, lotions and showers. Sanatorium buildings provide maximum comfort for persons with regard to their illness. Medical indications for therapeutic drink: digestive diseases, metabolic diseases and endocrine systems, professional heavy metal poisoning. Medical indications for external balneotherapy in the form of baths, showers and irrigation are cardiovascular disease with no more than first stage, diseases of the nervous system and locomotor system, gynecological diseases, skin diseases.

Recreational tourism also have nice places in Kazakhstan. Such as Bayanaul - a picturesque corner among the semi-desert steppe. The mountain slopes and valleys amaze of the abundance and dissimilarity of plant species. One who has ever been in the mountains Bajanaulsky necessarily pull back here to spend a healing vacation. Bayanaul Surrounding is climatic resort area, where from 1985 created Bayanaul National Park, the main attraction of which is nature. Mountain forest oasis of Bayanaul, covering an area of $450 \mathrm{~km}^{2}$, attracts tourists with bizarre rock formations (Baba Yaga, dove, Muffin, horse head, stone Perina et al.), with beautiful Sabyndykol and Zhasybay lakes, with caves (Aulietas and others) and grottos, with narrow gorges. Each year Zhasybai, Sabyndykol and Toraigyr lakes meet tourists all over the country. Therefore coast lakes are filled with recreational areas, houses and boarding houses for tourists.

District Kokshetau, also known as "Kazakh Switzerland" this is the second name of this amazing area in northern Kazakhstan. Among yellow, parched and endless steppes suddenly "grows" green wall of forest. Huge old trees, stone ridges, cliffs and fantastic twists quiet "bewitched" lake full of fish.

Okzhetpes one of the most beautiful rocks in Kazakhstan. Kazakhs say: "nobody will reach it even with an arrow." Pine forest is covered with white snow in winter, in the summer - light wind disperses around the aromatic waves of pine resin, in the autumn - the forest is full of special flavors : mixture of wet pine bark with mushrooms and herbs. There are also widespread birch forests.

Burabai is a unique place for those who collect medicinal herbs, the best place for rest and walking ... Burabai is resort, famous far beyond the borders of Kazakhstan, famous by hospitals, which practice improvement of health by using kumys - equine milk.

Charyn is the "city", where the main architect is nature. It is not built in the Medieval Gothic style, or modern constructivism. It is built entirely in a new style - the style of the unique natural landscapes. This is called "town" Charyn. It is located $195 \mathrm{~km}$ east of Almaty. "Charyn Canyon" is a beautiful monument of nature that has been preserved for millions of years, is extremely picturesque and very diverse in geological and geomorphological terms.

The height of the steep slopes of the canyon reaches $150-300 \mathrm{~m}$. The wind and water have created here beautiful "Valley of Castles". The length of the valley is more than $2 \mathrm{~km}$, width - 20 $80 \mathrm{~m}$. During the whole of the route you will be surrounded by bizarre tower, built of sedimentary rocks, whose age is about 12 million years. All this time the nature created this architecture, carefully and slowly, built majestic castles. You can spend hours wandering past the strange towers, poles and luxuriant imagination of nature.

Internet resourses for tourism marketing for Kazakhstan are duscribed below.

As well known, globalization leads to the development and introduction of new information technologies for the rapid transfer of information directly to the user. The information represents particularly important role for this rapidly evolving universal sphere as tourism, which, being the center of sphere of business and humanitarian field, is becoming one of the most promising and cost-effective global tourism destinations. Modern 
trends of tourism development associated with increased values of the information in a person's life, and the information is characterized by increasing access and the use of modern communication technologies.

Thus, the Ministry of Industry and New Technologies of Kazakhstan intends to promote tourism through social media marketing. Domestic officials have expressed their interest in the process of promoting in social networks. The announcement was made during online conference on bnews.kz portal about prospects of development the tourism industry in Kazakhstan.

Can be formulated some basic rules on the basis of which should be prepared information materials.

First, tourists are not interested in advertising; they need cognitive and practical information, which, inter alia, may be advertising.

Second, the person will be taken seriously only what is written grammatically correct in his language. Grammatically incorrect and irreconcilable native language texts are the way to create persistent negative reputation.

Third, the information should be authentic and photographs copyrighted.

Publication of information about tourism on existing web resources (for example, the famous "Wikipedia") and web sites of tourist orientation (such as www.virtualtourist.com, www.bootsnall.com or www.wikitravel.com), which each day is visited by tens and hundreds of thousands of potential customers. We should also mention the numerous forums where people are discussing it, where, how and when to go, as well as resources like "Youtube" or "Panoramio", where you can post photos and videos. So, below links to videos of Kazakhstan, which is officially called "Welcome to Kazakhstan", as well as links to social networks, the information that will be useful for all tourists and visitors (Table 1).

Table 1

Internet resourses deals with tourism marketing for Kazakhstan

\begin{tabular}{|c|c|}
\hline Video resources: & Social network: \\
\hline $\begin{array}{l}\text { https://www.youtube.com/watch?v=STTTSBUOGJs } \\
\text { Welcome to Kazakhstan } \\
\text { https://www.youtube.com/watch?v=7adGzUOUOhE } \\
\text { video by the Kazakhstan tourism industry Committee } \\
\text { https://www.youtube.com/watch?v=BfTCV865Cns } \\
\text { Kazakhstan is heart of Eurasia } 1 \text { st part } \\
\text { https://www.youtube.com/watch?v=MO5zOGMJQi } \\
\text { Kazakhstan is heart of Eurasia } 2^{\text {nd }} \text { part } \\
\text { https://www.youtube.com/watch?v=NU84_FiY72I } \\
\text { Astana is the capital city of Kazakhstan } \\
\text { https:// /www.youtube.com/watch?v=hDyspfco51Y } \\
\text { Astana } \\
\text { https:// } \\
\text { Almww.youty is city-megapolis } \\
\text { https:// www.youtube.com/watch?v=zWDzeFV-HtQ } \\
\text { Nature of Kazakhstan } \\
\text { https://www.youtube.com/watch?v=cM7OfplNns4 } \\
\text { Nature of Kazakhstan and Astana }\end{array}$ & $\begin{array}{l}\text { https://www.facebook.com/pages/Visit- } \\
\text { Kazakhstan/662915447112703?ref_type=bookmark } \\
\text { Travel and Leisure } \\
\text { https://www.facebook.com/ilovekz?fref=ts } \\
\text { News and Media about Kazakhstan } \\
\text { https://www.facebook.com/welcometokaz?ref=ts\&fref= } \\
\text { ts } \\
\text { Tourist agencies and Museums } \\
\text { https://www.facebook.com/BcdTravelKazakhstan?ref= } \\
\text { ts\&fref=ts } \\
\text { Organizing business trips and events }\end{array}$ \\
\hline
\end{tabular}

\section{Collected by the authors}

Opening and maintenance of own Internet resource, of course, in a foreign language and in several languages (but with respect for the principle of grammatical correctness). And the more it will provide useful information, the faster it will find a potential client by typing in a search "tourism in Kazakhstan".

It is important to understand one thing that nothing in our days is helping to spread information faster than the Internet. For example, if you post today on the website information, then within a week it will be spelled out in most of the search engines.
Good examples are the English-language websites of international tourist company "Oriental Express Central Asia" (www.orexca.com) and "Advan tour" (www.advantour.com), as well as the German-language website of the German tour company "Kasachstan Reisen" (www.kasachstanreisen.de).

These sites contain so much information about Kazakhstan that advertising, at first glance, is not evident. Person goes to advertising naturally, already having an idea of where he wants to go and what he wants to see (Table 2).

Kazakhstan tourism websites

\begin{tabular}{|c|c|c|c|}
\hline $\begin{array}{c}\text { State websites } \\
\text { management, development of } \\
\text { tourisms }\end{array}$ & $\begin{array}{c}\text { Public sites } \\
\text { provision, upgrading of } \\
\text { tourism }\end{array}$ & $\begin{array}{l}\text { Cor } \\
\text { provision, } s\end{array}$ & t services \\
\hline $\begin{array}{l}\text { www.kit.gov.kz } \\
\text { Committee of Tourism Industry of } \\
\text { the Ministry of Industry and New } \\
\text { Technologies of the Republic of } \\
\text { Kazakhstan }\end{array}$ & $\begin{array}{l}\text { http://www.kaztour- } \\
\text { association.com/ } \\
\quad \text { Kazakhstan } \\
\text { Association } \\
\text { http://astana-tourism.kz/ }\end{array}$ & $\begin{array}{l}\text { Tour operator } \\
\text { companies } \\
\text { www.intravel.kz } \\
\text { www.nicetravel.kz }\end{array}$ & $\begin{array}{l}\text { Travel agencies } \\
\text { http://www.silktour.k } \\
\text { z/ }\end{array}$ \\
\hline
\end{tabular}


International Relations. Economics. Country Studies. Tourism (IRECST)

\begin{tabular}{|c|c|c|c|}
\hline $\begin{array}{l}\text { http://www.kazakhstan.travel/ } \\
\text { Official Tourism Portal of the } \\
\text { Republic of Kazakhstan } \\
\text { http://visitkazakhstan.kz/ } \\
\text { Republican tourist portal } \\
\text { http://www.almatytourism.kz/ } \\
\text { Tourism development department } \\
\text { of Almaty city } \\
\text { http://tourismuko.gov.kz/ } \\
\text { Department of tourism of the } \\
\text { South-Kazakhstan region } \\
\text { http://www.tourism- } \\
\text { vs.vko.gov.kz/ } \\
\text { Department of Tourism and } \\
\text { Foreign Relations of the East } \\
\text { Kazakhstan region } \\
\text { http://upt.sko.gov.kz/ } \\
\text { Department of enterprise and } \\
\text { tourism in the North-Kazakhstan } \\
\text { region } \\
\text { http://www.kasachstan- } \\
\text { tourismus.de/ } \\
\text { Official tourism portal of } \\
\text { Kazakhstan in Germany }\end{array}$ & $\begin{array}{l}\text { Astana } \\
\text { Association (the organization } \\
\text { which seeks to develop } \\
\text { domestic tourism in Astana). } \\
\text { http://www.kagir.kz/ } \\
\text { Kazakhstan association of } \\
\text { hotels and restaurants } \\
\text { http://www.eco-tourism.kz/ } \\
\text { Information Resource } \\
\text { Center of Ecotourism } \\
\text { http://www.turan-profi.kz/ } \\
\text { International Vocational } \\
\text { Academy. Innovative projects: } \\
\text { Association curative - health } \\
\text { tourism of Kazakhstan, } \\
\text { Research Center of Tourism } \\
\text { and Service. }\end{array}$ & $\begin{array}{l}\text { www.iturist.kz } \\
\text { www.akmolatourist. } \\
\text { kz }\end{array}$ & $\begin{array}{l}\text { http:/ / www.travelclub } \\
\text {.kz/ } \\
\text { http: / / www.hottour.k } \\
\text { z/ } \\
\text { http: / / chemodan.kz/ } \\
\text { http:/ / orexca.com/ } \\
\text { http:/ / www.nomadic. } \\
\text { kz/ } \\
\text { http: / / www.allseason } \\
\text { s.kz/ } \\
\text { http:/ / voyage- } \\
\text { travel.kz/ } \\
\text { http: / / www.khantura } \\
\text { n.com/ } \\
\text { http:/ / algritravel.kz/ } \\
\text { http:/ / www.farabtouri } \\
\text { sm.kz/ } \\
\text { http:/ / oasis-1.kz/ } \\
\text { http:// travelhouse.kz/ } \\
\text { http:/ / abditravel.kz/ } \\
\text { http:/ / centertour.kz/ }\end{array}$ \\
\hline
\end{tabular}

Collected by the authors

Conclusion. Summing, Slovakia and Kazakhstan have a huge amount of cultural property, excellent natural conditions, as well as many places connected with the life and work of various historical figures. Countries have favorable climatic conditions, varied terrain and good ecology, snow-capped peaks, mountain rivers, prairies, pine forests, mirror lakes and many national parks. In addition, Slovakia and Kazakhstan are famous for its historical past: ancient castles, mausoleums, historical town, preserved through careful attitude to the monuments. Thus, we can say with confidence that these countries are very promising in terms of conducting tourism activities and have great potential for further development of tourism.
Nature generously endowed this land of rare beauty; it has everything what tourist may be interested. Tourism industry in these countries provides an excellent opportunity to get acquainted with its cultural and historical attractions, many of which have been preserved in its original form. Besides the huge number of monuments of primitive times, reflecting the desire of the visual arts in ancient times, on the basis of surviving in the territory of Slovakia and Kazakhstan documents historical era to the smallest detail can trace the development of architecture, sculpture, painting and other artistic whole millennium.

\section{ПОРІВНЯАЬНИЙ ОГАЯД ПРИРОДНИХ І КУАЬТУРНИХ КОМПОНЕНТІВ МАРКЕТИНГОВОЇ СЕРЕДОВИЩА ДАЯ ТУРИЗМУ В КАЗАХСТАНІ І САОВАЧЧИНИ}

Кумтан Ярослав, кандидат наук, доцент, кафедра прикладної інформатики, Братиславський економічний університет, Словаччина

мухаммедов Абу, доктор технічних наук, професор, кафедра фінансів та бухгалтерії, Університет міжнародного бізнесу, Казахстан

Дорохова Мюдмима, кандидат наук, доцент, кафедра фармацевтичного менеджменту та маркетингу, Національний фармацевтичний університет, Україна

Мамий Вомодимир, доктор технічних наук, професор, кафедра фармацевтичного менеджменту та маркетингу, Національний фармацевтичний університет, Україна

Дорохов Охександр, кандидат наук, доцент, кафедра інформаційних систем, Харківський національний економічний університет імені Саймона Кузнеця, Україна, e-mail: aleks.dorokhov@meta.ua

Незважаючи на катастрофічне скорочення в даний час туристичних послуг і супутніх сервісів в світі в умовах пандемії, питання розвитку туризму в перспективі залишаються дуже актуальними, особливо в очікуванні переформатування світового туристичного ринку, як одного з результатів закінчення пандемії. При цьому, поряд з традиційними світовими центрами туризму, можна припустити виникнення нових регіональних і глобальних країн, мідерів туризму. Майбутній перезапуск ринку дасть хорошу, рідкісну можливість для нових туристичних напрямків заявити про себе, активізувати залучення туристів і зайняти певні позиції на перезавантажувати туристичному ринку. Тому опрацювання своїх потенційних можливостей і усвідомлення своїх конкурентних маркетингових переваг є важливим для таких держав, які розвивають туризм. Відповідно, дане дослідження присвячене проблемі розвитку туристичної індустрії, зокрема, опису i аналізу природних умов і відповідних можливостей для розвитку оздоровчого, спортивного, освітньо пізнавального туризму в Республіці Словаччина та Республіці Казахстан. Дан детальний порівняльний аналіз соціокультурних і природно-географічних компонентів маркетингового середовища для розвитку туризму в 
обох країнах. Докладно розглянуті такі популярні і затребувані в міжнародному туризмі напрямки, як гірський і гірськолижний, культуро-історичний і пізнавальний, медичний і мікувально-оздоровчий, а також рекреаційний туризм. В цілому, розглядаються країни мають багато спільного щодо різноманітних можливостей і видів туризму. Однак в силу ряду історичних, географічних, суспільно-соціальних причин, рівень розвитку туристичного сервісу в них сильно відрізняється. Також в цьому дослідженні порівнюються можливості для розвитку відповідного туризму в Словаччині та Казахстані. Щоб уявити туризм дия іноземних туристів і створити позитивний імідж Словаччини та Казахстану як сприятливих країн дмя в'їзного туризму, необхідно активно використовувати сучасні інформаційні технології та інновації. У даній статті представцені такі джерела інформації про туристичний потенціал, як веб-сайти, посилання на інтернет ресурси туристичних агентств і операторів, на основні відео ресурси про можливості туризму в Республіці Казахстан. Розвиток цих нововведень дозволить Республіці Казахстан увійти в число найбільш конкурентоспроможних у туристичному сервісі країн і стати новим значним світовим туристичним центром.

Ключові слова: туристичний потенціал Казахстану, туристичні переваги Словаччини, туристичний маркетинг.

\section{СРАВНИТЕАЬНЫЙ ОБЗОР ПРИРОДНЫХ И КУАЬТУРНЫХ КОМПОНЕНТОВ МАРКЕТИНГОВОЙ СРЕДЫ ДАЯ ТУРИЗМА В КАЗАХСТАНЕ И САОВАКИИ}

Кумтан Ярослав, кандидат наук, доцент, кафедра прикладной информатики, Братиславский экономический университет, Словакия

Мухаммедов Абу, доктор технических наук, профессор, кафедра финансов и бухгалтерии, Университет международного бизнеса, Казахстан

Дорохова Аюдмима, кандидат наук, доцент, кафедра фармацевтического менеджмента и маркетинга, Национальный фармацевтический университет, Украина

Малый Вцадимир, доктор технических наук, профессор, кафедра фармацевтического менеджмента и маркетинга, Национальный фармацевтический университет, Украина

Дорохов Амександр, кандидат наук, доцент, кафедра информационных систем, Харьковский национальный экономический университет имени Саймона Кузнеца, Украина, е-таil: aleks.dorokhov@meta.ua

Несмотря на катастрофическое сокращение в настоящее время туристических услуг и сопутствующих сервисов в мире в условиях пандемии, вопросы развития туризма в перспективе остаются весьма актуальными, особенно в ожидании переформатирования мирового туристического рынка, как одного из результатов окончания пандемии. При этом, наряду с традиционными мировыми центрами туризма, можно предположить возникновение новых региональных и глобальных стран, мидеров туризма. Предстоящий перезапуск рынка даст хорошую, редкую возможность для новых туристических направлений заявить о себе, активизировать привлечение туристов и занять определенные позиции на перезагружающемся туристическом рынке. Поэтому проработка своих потенциальных возможностей и осознание своих конкурентных маркетинговых преимуществ является важным для таких государств, развивающих туризм. Соответственно, данное исследование посвящено проблеме развития туристической индустрии, в частности, описанию и анализу природных условий и соответствующих возможностей для развития оздоровительного, спортивного, образовательно познавательного туризма в Республике Словакия и Республике Казахстан. Дан детальный сравнительный анализ социокультурных и природно-географических компонентов маркетинговой среды для развития туризма в обеих странах. Подробно рассмотрены такие популярные и востребованные в международном туризме направления, как горный и горнолыжный, культуроисторический и познавательный, медицинский и мечебно-оздоровительный, а также рекреационный туризм. В целом, рассматриваемые страны имеют много общего относительно разнообразных возможностей и видов туризма. Однако в силу ряда исторических, географических, общественно-социальных причин, уровень развития туристического сервиса в них сильно отличается. Также в этом исследовании сравниваются возможности для развития соответствующего туризма в Словакии и Казахстане. Чтобы представить туризм для иностранных туристов и создать позитивный имидж Словакии и Казахстана как благоприятных стран дия въездного туризма, необходимо активно использовать современные информационные технологии и инновации. В данной статье представлены такие источники информации о туристическом потенциале, как веб-сайты, ссылки на интернет ресурсы туристических агентств и операторов, на основные видео ресурсы о возможностях туризма в Республике Казахстан. Развитие этих нововведений позволит Республике Казахстан войти в число наиболее конкурентоспособных в туристическом сервисе стран и стать новым значительным мировым туристическим центром.

КАючевые слова: туристический потенциал Казахстана, туристические преимущества Словакии, туристический маркетинг

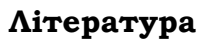

1. Aliyeva1, S., Chen, X., Yang, D., Samarkhanov, K., Mazbayev, O., Sekenuly, A., Issanova, G., Kozhokulov, S. The Socioeconomic Impact of Tourism in East Kazakhstan Region: Assessment Approach. Sustainability. 2019. Vol. 11(17). 1-14.
} 
2. Allayarov, P., Embergenov, B., Si Thu Han. Problems and Prospects of sustainable tourism in the Republic of Kazakhstan. Business and Economic Research. 2018. Vol. 8(2). 115-126.

3. Ayetov, S., Uruzbayeva, N. Current Issues of Inbound Tourism in the Republic of Kazakhstan and Ways of Promotion. Journal of Advanced Research in Management. 2018. Vol. 9(6). 1202-1209.

4. Bancerova, O., Kasimova, A. Formation of Ethnocultural Tourism Clusters in Russia Kazakhstan Borderline Territory. Journal of Advanced Research in Managemen. 2018. Vol. 9(4), 771-776.

5. Kasagranda, A., Gurňák D. Spa and Wellness Tourism in Slovakia (A Geographical Analysis). Czech Journal of Tourism. 2017. Vol. 6(1), 27-53.

6. Kosikova, M., Vasanicova, P., Litavcova, E. Analysis of aspects of the tourism development in Slovakia in the Context of the European Space. Montenegrin Journal of Economics. 2019. Vol. 15(2), $127-137$.

7. Kulakhmetova, G., Hnatkovych, O., Rusnak, A., Shcherbakova, N. The Way to the Leading Positions in World Tourism Case Study of Kazakhstan. Journal of Advanced Research in Management. 2018. Vol. 9(6), 1289-1295.

8. Malchrowicz-Mośko, E., Botiková, Z., Poczta, J. Because We Don’t Want to Run in Smog: Problems with the Sustainable Management of Sport Event Tourism in Protected Areas (A Case Study of National Parks in Poland and Slovakia). Sustainability. 2019. Vol. 11(2), 1-20.

9. Öğüt, K., Yeşilyurt, S., Yurtseven, Ç. Health Tourism between Kazakhstan and Turkey: Outlook on Health Sectors and Potentials. Business and Economics Research Journal. 2018. Vol. 9(1), 57-74.

10.Shevyakova, A., Munsh, E., Arystan, M. Towards diversification of the economy of Kazakhstan via information support for the tourism industry, Entrepreneurship and Sustainability. 2019. Vol. 1(2), $129-137$.

11.Štrba, L., Kolačkovská, J., Kudelas, D., Kršák, B., Sidor, C. Geoheritage and Geotourism Contribution to Tourism Development in Protected Areas of Slovakia, Theoretical Considerations. Sustainability. 2020. Vol. 12(7), 1-20.

12.Tleubayeva, A. Rural Tourism as One of the Priority Factors for Sustainable Development of Rural Territories in Kazakhstan. Journal of Advanced Research in Management. 2018. Vol. 9(6), 1312-1326.

13.Trusheva, S., Syzdykbaeva, B. Prospects and Development of Tourism in Kazakhstan and the Impact of Incentive Tours on Efficiency, European Research Studies Journal. 2018. Vol. 3, 727-737.

\section{References}

1. Aliyeva1, S., Chen, X., Yang, D., Samarkhanov, K., Mazbayev, O., Sekenuly, A., Issanova, G., Kozhokulov, S. (2019). The Socioeconomic Impact of Tourism in East Kazakhstan Region: Assessment Approach. Sustainability, Vol. 11(17), 1-14.

2. Allayarov, P., Embergenov, B., Si Thu Han. (2018). Problems and Prospects of sustainable tourism in the Republic of Kazakhstan. Business and Economic Research, Vol. 8(2), 115-126.

3. Ayetov, S., Uruzbayeva, N. (2018). Current Issues of Inbound Tourism in the Republic of Kazakhstan and Ways of Promotion. Journal of Advanced Research in Management, Vol. 9(6), 1202-1209.

4. Bancerova, O., Kasimova, A. (2018). Formation of Ethnocultural Tourism Clusters in Russia Kazakhstan Borderline Territory. Journal of Advanced Research in Management, Vol. 9(4), 771-776.

5. Kasagranda, A., Gurňák D. (2017). Spa and Wellness Tourism in Slovakia (A Geographical Analysis). Czech Journal of Tourism, Vol. 6(1), 27-53.

6. Kosikova, M., Vasanicova, P., Litavcova, E. (2019). Analysis of aspects of the tourism development in Slovakia in the Context of the European Space. Montenegrin Journal of Economics, Vol. 15(2), 127-137.

7. Kulakhmetova, G., Hnatkovych, O., Rusnak, A., Shcherbakova, N. (2018). The Way to the Leading Positions in World Tourism Case Study of Kazakhstan. Journal of Advanced Research in Management, Vol. 9(6), 1289-1295.

8. Malchrowicz-Mośko, E., Botiková, Z., Poczta, J. (2019). Because We Don’t Want to Run in Smog: Problems with the Sustainable Management of Sport Event Tourism in Protected Areas (A Case Study of National Parks in Poland and Slovakia). Sustainability, Vol. 11(2), 1-20.

9. Öğüt, K., Yeşilyurt, S., Yurtseven, Ç. (2018). Health Tourism between Kazakhstan and Turkey: Outlook on Health Sectors and Potentials. Business and Economics Research Journal, Vol. 9(1), 57-74.

10.Shevyakova, A., Munsh, E., Arystan, M. (2019). Towards diversification of the economy of Kazakhstan via information support for the tourism industry, Entrepreneurship and Sustainability, Vol. 1(2), $129-137$.

11.Štrba, L., Kolačkovská, J., Kudelas, D., Kršák, B., Sidor, C. (2020). Geoheritage and Geotourism Contribution to Tourism Development in Protected Areas of Slovakia, Theoretical Considerations. Sustainability, Vol. 12(7), 1-20.

12.Tleubayeva, A. (2018). Rural Tourism as One of the Priority Factors for Sustainable Development of Rural Territories in Kazakhstan. Journal of Advanced Research in Management, Vol. 9(6), 1312-1326.

13.Trusheva, S., Syzdykbaeva, B. (2018). Prospects and Development of Tourism in Kazakhstan and the Impact of Incentive Tours on Efficiency, European Research Studies Journal, Vol. 3, 727-737. 